\title{
Alternative INDICATORS FOR CHINESE ECONOMIC ACTIVITy Using SPARSE PLS REGRESSION
}

\author{
Jan J. J. Groen and Michael B. Nattinger
}

\section{OVERVIEW}

- According to official GDP data, China's economy has experienced a remarkably - and perhaps unrealistically - smooth deceleration since the Great Recession. Alternative data sources suggest greater volatility, however, with many China watchers seeing evidence that cyclical downturns occurred in 2015-16 and 2018-19.

- To better track Chinese business cycle fluctuations, the authors construct an economic activity indicator using factors from a sparse partial least squares (PLS) regression on a wide array of high-frequency data. The resulting indicator points to a greater degree of cyclicality in Chinese economic growth than official statistics reflect.

\section{- Decomposing deviations} from trend growth, the authors also find that domestic factors have eclipsed external factors as the primary driver of Chinese economic activity since 2018, citing a deterioration in domestic credit conditions as the main cause of the 2018-19 slowdown.

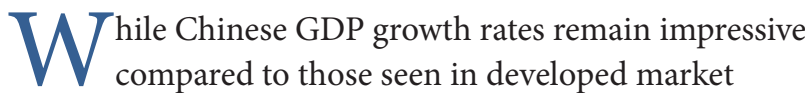
economies, the Chinese economy has been decelerating since the 2007-09 Great Recession. Remarkably, this slowdown seems to be proceeding in a smooth fashion. ${ }^{1}$ However, alternative, higher-frequency data, as well as reports about firm and household behavior, suggest that Chinese growth has been more cyclical over this period than the official numbers imply.

For example, market participants and academics believe that China has experienced two cyclical downturns in the $\mathrm{Xi}$ Jinping era (2013-present) - one in 2015-16 and another in 2018-19. However, neither of these downturns appears in the official GDP data, which have continued to reflect a gradual and orderly deceleration in China's economy throughout this period. Consequently, there is widespread doubt about the reliability of official Chinese GDP data. Chen et al. (2019), for example, look at changes in VAT receipts to quantify over- and underreporting in official GDP numbers, finding that such errors occur frequently and are quantitatively large-problems they attribute to data collection and construction issues within statistical authorities at both the local and national levels. ${ }^{2}$

Jan J. J. Groen is an officer at the Federal Reserve Bank of New York. Michael B. Nattinger, now at the University of Wisconsin-Madison, made his contributions to this paper while working as a senior research analyst at the Federal Reserve Bank of New York. Email: jan.groen@ny.frb.org; nattinger@wisc.edu.

The views expressed in this article are those of the authors and do not necessarily reflect the position of the Federal Reserve Bank of New York or the Federal Reserve System. To view the authors' disclosure statements, visit https://www.newyorkfed.org/research/ epr/2020/epr_2020_china-sparse-pls_groen. 
In an attempt to better track Chinese business cycles, China watchers have constructed a wide array of growth indicators based on alternative data. The most well-known of these alternative indicators is the so-called Li Keqiang index, which is essentially an arithmetic average of the growth rates of electricity production, railroad freight, and bank loans in China. ${ }^{3}$

Academic studies, such as Clark, Pinkovskiy, and Martin (2019) and Fernald, Hsu, and Spiegel (2019), have used more extensive data sets and more sophisticated aggregation schemes to construct alternative views of Chinese economic performance. Similarly, we propose a methodology that efficiently draws and combines indicator variables from a large pool of candidate variables to quantify an alternative view of the state of the Chinese economy.

Our methodology has several advantages as an alternative growth indicator. First, our indicator draws from an extensive pool of high-frequency data, all potentially related to Chinese economic performance. Our methodology then weeds out series that provide less information about underlying economic growth. Next, we target the underlying data to a set of economic indicators that are highly correlated with various important aspects of the Chinese economy. The end results are factors from a sparse partial least squares (PLS) regression that appear to track Chinese business cycles at a high frequency, perform well out-of-sample, and, as shown in Clark, Dawson, and Pinkovskiy (2019), correlate well with an array of growth indicators from around the world. Finally, our factor model enables us to decompose China's deviations from trend growth into global growth, credit supply, and monetary policy components.

\section{Modeling Approach}

As noted above, a number of studies indicate that Chinese GDP data might suffer from a number of measurement issues, which make them a less reliable indicator of fluctuations in economic activity. We shall treat Chinese economic activity as not observable and approximate it by making use of higher-frequency correlations between proxies of Chinese economic activity and an array of survey, production, sales, and financial market variables.

To model these correlations, we start with the following relationship:

$$
\Delta y_{t}=\alpha_{0}+\alpha^{\prime} x_{t}+\epsilon_{t} ; \quad t=1, \ldots, T
$$

where $t$ represents an observation at the monthly frequency, $\Delta y_{t}=100\left(\ln \left(Y_{t}\right)-\ln \left(Y_{t-12}\right)\right)$, with $Y_{t}$ being a $k \times 1$ vector of economic activity proxies and $x_{t}$ an $N \times 1$ vector of normalized variables (either in terms of percentage changes or log levels, depending on what yields an $I(0)$ series). Given the size of our data set, $N$ in (1) becomes quite large. A common way to deal with large dimensionality in the context of (1) is to extract a limited number of common factors from $x_{t}$; see the discussion in Groen and Kapetanios (2016). However, only those common factors that best reflect the correlations between the economic activity proxy variables and the variables in $x_{t}$, both contemporaneously as well as dynamically, are of interest for our exercise. Hence, only specific methods of common factor estimation can be used and one of those approaches is PLS regression.

To execute the PLS regression described in (1), one constructs $r$ independent, linear combinations of $x_{t}$ that have the highest covariance with $\Delta y_{t}: f_{t}=\left(f_{1, t}, \ldots, f_{r, t}\right)^{\prime}$. This implies that 
PLS factors can be defined as $\left(f_{1}^{\prime} \cdots f_{T}^{\prime}\right)^{\prime}=X W, X=\left(x_{1}^{\prime} \cdots x_{T}^{\prime}\right)^{\prime}, W=\left(w_{1} \cdots w_{r}\right)$ (see also Groen and Kapetanios [2016]). For each factor, the corresponding loadings, $w_{r}$, can be estimated as

$$
w_{r}=\max _{w} w^{\prime}\left(X^{\prime} \Delta \tilde{y}\right)\left(X^{\prime} \Delta \tilde{y}\right)^{\prime} w \quad \text { s.t. } \quad w^{\prime} w=1 \quad \text { and } \quad w^{\prime}\left(X^{\prime} X\right) w_{j}=0
$$

with $\Delta \tilde{y}_{t}$ being the normalized activity proxies, $\Delta \tilde{y}=\left(\Delta \tilde{y}_{1}^{\prime} \ldots \Delta \tilde{y}_{T}^{\prime}\right)^{\prime}$ and $j=1, \ldots, r-1$.

(2) boils down to estimating $w_{r}$ using the eigenvector corresponding to the largest eigenvalue of the squared covariance matrix of the activity proxies, with the variables in $X$ conditional on the effect of the previous $r-1$ factors.

In its standard setup, as described above, PLS regression estimates factors that have contributions from all $N$ variables in $x_{t}$. One disadvantage of using factor models to summarize the information in a relatively large, heterogeneous data set is that when $N$ expands-and $x_{t}$ contains noisy variables-the factors could become imprecise, generating a case of "weak" or "near-strong" factors. In contrast to more standard factor estimation methods that solely maximize the fit for $x_{t}$ and do not target a dependent variable, such as principal component analysis, PLS regression can be a useful tool for estimating appropriate factors, even when these are weak, just because it also targets a dependent variable. However, when using PLS regression, there is also the risk of overfitting the data, in particular when $N$ is large.

Groen and Kapetanios (2016, Theorem 2) formally explore the behavior of PLS regression in the weak factor case, showing that it works as long as the number of variables underlying the factors grows at a slower rate than the number of time series observations. One way to impose this condition in practice is to use sparse PLS regression as devised by Chun and Keles (2010), which in essence builds a group least absolute shrinkage and selection operator (LASSO) restriction into the standard PLS estimation approach (2), that is,

$$
w_{r}=\max _{w} w^{\prime}\left(X^{\prime} \Delta \tilde{y}\right)\left(X^{\prime} \Delta \tilde{y}\right)^{\prime} w \quad \text { s.t. } \quad w^{\prime} w=1, \quad|w| \geqq \lambda
$$

$$
\text { and } w^{\prime}\left(X^{\prime} X\right) w_{j}=0
$$

with $\lambda=\bar{\lambda} \times \max \left|w_{r}\right|$ and $0<\bar{\lambda}<1$. Intuitively, a group LASSO restriction, through $\lambda$ in (3), yields the relevant subset of the $N$ variables, given the strength of the individual correlations with the activity proxies. Standard PLS estimation is then applied in a final step to get the appropriate factors $f_{t}$ in (4). This LASSO restriction also reduces the potential risk of overfitting that comes with applying PLS regression. Hence, variables, and the common factors derived from these, are selected and rotated based on their relevance to the correlation with activity proxies.

In order to be able to estimate a sparse PLS factor model, one needs to determine the number of PLS factors, $r$, and the degree of sparsity, $\bar{\lambda}$, in (3). This is done with the Bayesian Information Criterion (BIC) using a stochastic degrees of freedom measure for PLS regression, as developed in Krämer and Sugiyama (2011). For a given set of $r$ and $\bar{\lambda}$ values, we fit

$$
\Delta y_{t}=\beta_{0}+\beta^{\prime} f_{t}+\varepsilon_{t} ; \quad t=1, \ldots, T,
$$


and compute the corresponding BIC criterion

$$
B I C-P L S=T \ln \left(\left|\Sigma_{\hat{\varepsilon}}\right|\right)+\left(\sum_{m=1}^{k}\left(1+r+\operatorname{trace}\left(\frac{\partial \Delta \hat{y}_{m, t}(r)}{\partial \Delta y_{m, t}}\right)\right)\right) \ln (T),
$$

where $\Sigma_{\hat{\varepsilon}}$ is the matrix of the mean squared fitting errors of (4) and $\frac{\partial \Delta \hat{y}_{m, t}(r)}{\partial \Delta y_{m, t}}$ is the first derivative of the fitted value for the activity proxy variable $m$ based on $r$ PLS factors, since the estimated PLS factors themselves depend on the activity proxies. The lower the collinearity among the $x_{t}$ variables used in the sparse PLS estimation, the higher this derivative will be, and this collinearity will be partly regulated by the number of variables selected for the PLS factor estimated through the value of sparsity parameter, $\bar{\lambda}$, in (3).

After recasting all variables as year-over-year growth rates, we then purge very low-frequency variation from the data underlying $\Delta y_{t}$ and $x_{t}$; because our activity indicator is intended to measure the current state of Chinese economic activity, we filter out the effects any underlying trends. Following Stock and Watson (2012), each of the series underlying $\Delta y_{t}$ and $x_{t}$ is computed as a deviation from a time-varying mean that is approximated through a bi-weight kernel-based filter with a bandwidth of five years. Each series is then normalized and utilized in our sparse modeling approach. ${ }^{4}$

Under the assumption that the covariation between $\Delta y_{t}$ and $x_{t}$ is driven by a single primitive shock, we use $\hat{\gamma}^{\prime} f$, with $\hat{\gamma}$ being the result of the regression

$$
\sigma\left(\Gamma^{\prime}\left(\Delta y_{t}-\Delta \bar{y}_{t}\right)\right)=\gamma^{\prime} f_{t}+\varepsilon_{t} ; \quad t=1, \ldots, T .
$$

In (6), $\Delta \bar{y}_{t}$ collects the bi-weight kernel-based filtered trends of the variables in $\Delta y_{t} ; \Gamma$ is the $k \times 1$ loading vector corresponding to the largest principal component of $\left(\Delta y_{t}-\Delta \bar{y}_{t}\right)$; and $\sigma$ is a scaling variable that guarantees that the standard deviation of $\Gamma^{\prime}\left(\Delta y_{t}-\Delta \bar{y}_{t}\right)$ equals that of similarly de-trended, monthly interpolated, official GDP data. Our Chinese economic activity indicator thus equals:

$$
\Delta \text { pseudoGDP }{ }_{t}=\alpha_{t}+\hat{\gamma}^{\prime} \dot{f}_{t}
$$

where $\alpha_{t}$ is the bi-weight kernel-based filtered time-varying mean of the year-over-year GDP growth rate extracted from the official Chinese GDP data (interpolated to a monthly frequency), using a five-year window for the kernel.

\section{Results}

\subsection{Data}

We employ three versions of our sparse PLS factor model-based activity indicator, depending on the composition of the target variables, $\Delta y_{t}$. The first version utilizes a univariate growth target variable (so $k=1$ in (4)) and consists of the year-over-year growth rate of a proxy of 
Chinese imports; the second version adds a proxy of Chinese manufacturing activity to the imports measure as the target variables for (4); and the final version adds a proxy for Chinese retail sales to those activity proxies, bringing the total number of target variables in (4) to three. For the first and second versions of the indicator, $x_{t}$ contains forty-four Chinese economic activity variables, while the third version moves retail sales to the left-hand side of the equation, resulting in an $x_{t}$ containing forty-three variables. All three versions of the indicator are estimated on a monthly sample from January 2001 to March 2019.

For our first targeted growth proxy, we approximate Chinese import volumes with real exports as reported by China's largest trade partners: Japan, the United States, and the euro area. Fernald, Hsu, and Spiegel (2019) show that such figures are a strong proxy for Chinese economic growth.

One argument for that conclusion is that the proxy theoretically avoids the entire issue of incorrect or incomplete data, since there is less incentive for China's trade partners to falsify their data on China-bound exports. Another advantage is that these countries are likely to measure the exports leaving their ports more accurately than Chinese authorities measure the imports arriving at theirs.

When we tally up Chinese imports, we include imports to Hong Kong because, as Fernald, Hsu, and Spiegel (2019) have pointed out, a large proportion of these flows have China as their final destination. This relationship was especially true during the first few years of our sample, but for consistency we use the sum of exports from Japan, the United States, and the euro area to both Hong Kong and China over the entire sample. To account for inflation, we construct a U.S.-China trade deflator. After summing U.S. agricultural and nonagricultural exports (based on NAICS product-level categories) to China, we use the agricultural and nonagricultural U.S. export price indexes to create a weighted price deflator. We then apply this indicator to Chinese import data-as reported by all of the country's trade partners.

Our second target variable is a Chinese industrial production diffusion index. One main reason to focus on such a diffusion index is that, as a measure of dispersion of change, it quantifies the breadth of growth across the manufacturing sector, which is important in assessing the overall state of China's economy. There are two additional reasons why we focus on a manufacturing growth diffusion index as a target variable in our sparse PLS-based factor model. First, it is possible that Chinese industrial production data are biased at several levels of aggregation. China's National Bureau of Statistics (NBS) does not publish an index of industrial production, but instead releases estimates of value-added by industry (at current prices) and year-over-year growth rates (at constant prices). Local authorities gather a large portion of these real value-added estimates from firms, data that are then adjusted when the NBS aggregates the figures at the national level. Chen et al. (2019) report significant biases in the data-gathering procedures at the local level, as well as in the aggregation process. These biases are especially large for firms in industrial sectors.

In addition, there are inconsistencies and gaps in the Chinese industry-level data, with some sectors dropping out of the sample in certain months and reappearing in other months. A diffusion index can easily deal with the latter issue, and assuming that these aggregation biases are more or less equally distributed across industries, a diffusion index should still yield reasonably reliable insight on the breadth of an expansion or contraction in China's manufacturing sector. We therefore construct a diffusion index by determining, for a given month, the percentage of industrial sector-level series that have data exhibiting a higher year-over-year 
growth rate of real value-added than they did in the previous month. The diffusion index is thus similar to an industry-level purchasing managers' index (PMI). We exclude mining from our main index because mining activity is much more dependent on global commodity prices than the state of the domestic economy. ${ }^{5}$

Finally, the third target variable is a retail sales variable constructed from Chinese industry-level retail sales data, deflated using the relevant retail price indexes. As we exclude auto and petrol sales, we aggregate the remaining groupings into an overall real retail sales series, and construct a growth proxy by compiling the year-over-year growth rates of our real retail sales series. ${ }^{6}$

For the first two versions of our sparse PLS factor model-based activity indicator, the right-hand side of (4) involves forty-four variables covering Chinese survey, production, sales, and financial market data, spanning everything from electricity production and sectoral production data to M2 and stock price data. In the third version, $x_{t}$ consists of the same variables, with the exception of retail sales, which is moved to the left-hand side. These variables, as well as the three target variables described above, are seasonally adjusted using the U.S. Census Bureau's X-13 methodology (the financial variables are not adjusted). We then take the log year-over-year difference where appropriate, filter out remaining outliers, and de-trend our data using a bi-weight filter in the spirit of Stock and Watson (2012). ${ }^{7}$ Finally, we set all variables to unit variance.

Our data are collected from a wide variety of sources made available through Haver Analytics and CEIC Data.

\subsection{Chinese Official GDP Data vs. the Alternative Indicators}

For the three versions of our sparse PLS factor model-based activity indicator, we minimize (5) on the data using a grid of $r=1, \ldots, 10$ and $\bar{\lambda}=0.11,0.12,0.13, \ldots, 0.99$ in order to get optimal values for $r$ and $\bar{\lambda}$ that can be used in the corresponding (3) and (4) for each of these three versions. This specification search indicates that when only the Chinese import growth target variable is used (version 1), the optimal specification for the corresponding full sample sparse factor model should be based on $\bar{\lambda}=0.6$ and $r=3$; when both Chinese imports and the manufacturing production diffusion index are targeted (version 2), the sparse PLS model is based on $\bar{\lambda}=0.88$ and $r=3$; and finally, when imports, the manufacturing production diffusion index, and real retail sales are targeted, the underlying sparse PLS specification should be $\bar{\lambda}=0.77$ and $r=8$.

In terms of the number of variables used, these differences in specifications between the three versions of the sparse PLS factor model indicate that twenty-nine variables are used to construct an economic activity measure when targeted toward real import growth only; a mere four variables constitute the activity measure when targeted jointly toward import growth and the manufacturing growth diffusion index, whereas the sparse PLS model uses twenty-three variables to construct the activity measure when targeted toward import growth, the manufacturing growth diffusion index, and the real retail sales growth proxy (see Table 1A in Appendix 1). Some variables-electricity production, value-added by industry, auto sales, and PPI-are included in all three versions of our sparse factor model, but versions 1 and 3 also incorporate additional survey, financial, price, and trade variables. 
Chart 1

Comparing China's Official GDP Growth to Alternative Indicators

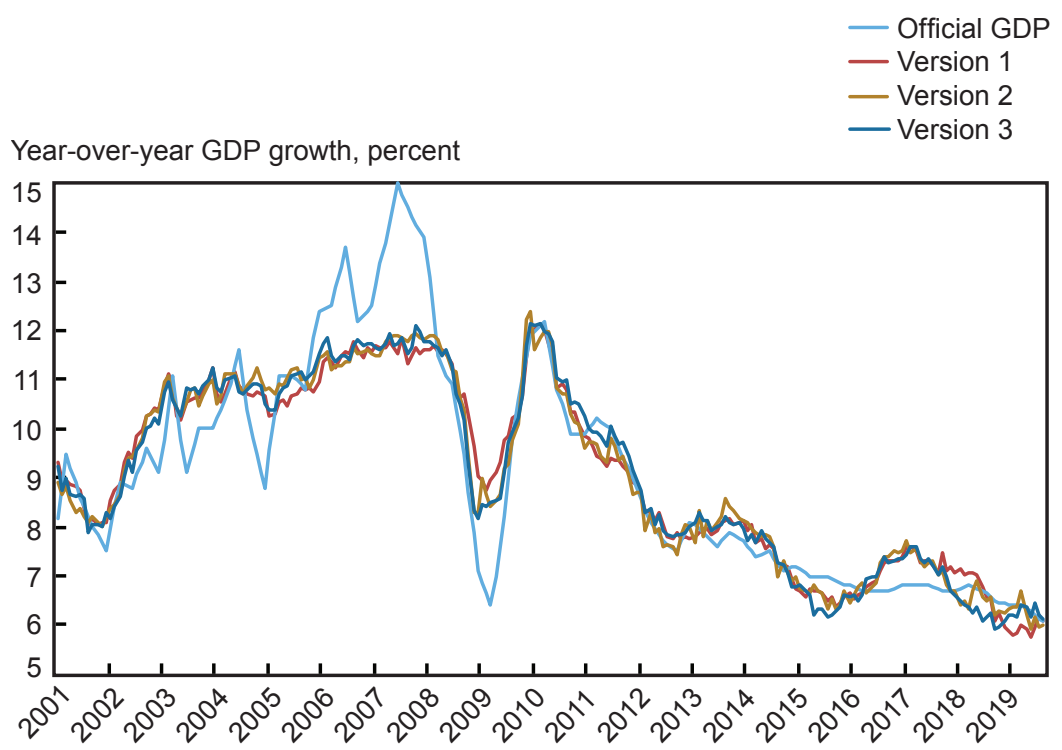

Source: Authors' calculations; National Bureau of Statistics of China, accessed through CEIC.

Note: Chart shows three versions of the authors' sparse PLS factor model-based activity indicator.

We compare our three sparse PLS-based indicators of economic activity with the official Chinese GDP data in Chart 1. A first observation from this chart is that our three alternative activity indicators behave rather similarly despite the specification differences. What also becomes apparent from Chart 1 is that before 2010, the alternative indicators suggest that economic activity was less volatile than the official GDP data suggest, whereas from 2010 onward this pattern reverses, with official Chinese GDP data becoming far less volatile than our indicators.

For example, between 2005 and 2008, official statistics show a sharp acceleration in growth-from 9 percent to 15 percent-whereas the alternative indicators point to a far more gradual growth acceleration. Likewise, for the 2014-19 period, these indicators suggest significant growth accelerations and slowdowns, but the official GDP growth data remain essentially flat.

To get an idea of how a real-time application of the sparse PLS factor model-based indicators would perform, and also to get a sense of the stability of the underlying models, we can recursively re-estimate the sparse PLS models and generate out-of-sample estimates of Chinese economic activity.

More specifically, we start off with a subsample of data from January 2001 to March 2011, which we use to estimate our three sparse PLS models (including cross-validating the appropriate number of factors and the number of variables used for this subsample). Keeping the estimated model parameters constant, data for the next month are then used in the models to generate projections of Chinese economic activity in that month. We then add that month of 
Chart 2

Chinese Economic Indicators: Full Sample vs. Out-of-Sample

- Full-sample estimates

.... Out-of-sample estimates

Year-over-year GDP growth, percent

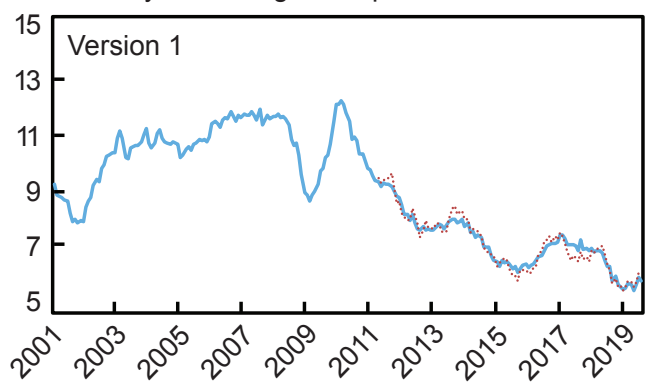

Year-over-year GDP growth, percent

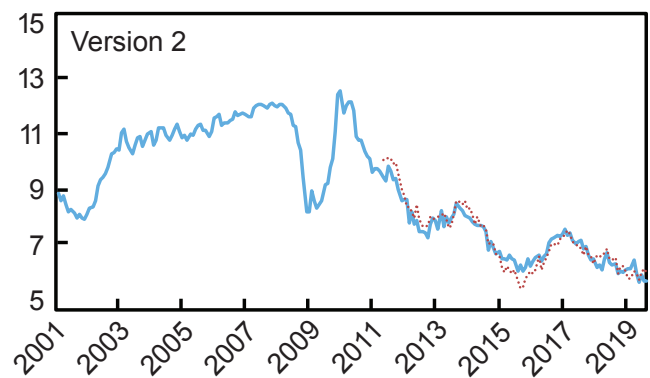

Year-over-year GDP growth, percent

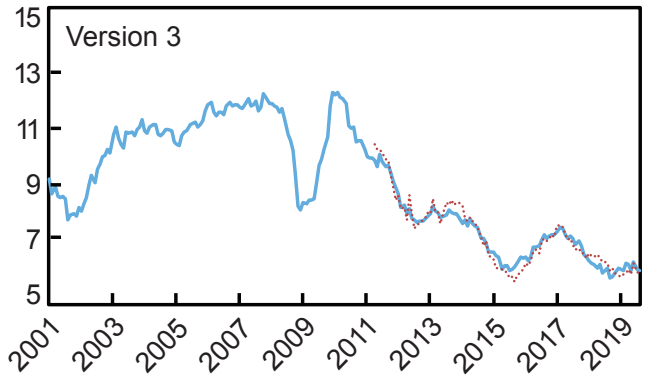

Source: Authors' calculations.

Note: The panels show full-sample and out-of-sample estimates for each version of the authors' sparse PLS factor model-based activity indicator.

data (April 2011) to the initial subsample (January 2001-March 2011), then go through the previous steps once again. All of this is repeated until we reach the end of our full data sample.

Chart 2 depicts both the full-sample estimates (as also shown in Chart 1) and the out-ofsample evolutions for all three variations of our sparse PLS-based economic indicators. Compared to the full-sample estimates, the recursive projections for all three versions of the model at times appear to reflect a slightly more optimistic or pessimistic view on growth in China, but they nonetheless converge fairly quickly toward the full-sample estimates. In summary, the model structures underlying our estimates of Chinese economic activity seem to be relatively stable over time.

Another way to assess the usefulness and robustness of our approach is to apply our methodology for China to economies for which high-quality data are available. As an example of a large economy, we use the United States, and as an example of an East Asian export-oriented economy that has outgrown developing economy status fairly recently, we use South Korea.

For both economies, we apply our sparse PLS-based factor approach in the same manner as we did for China - that is, we use an identical monthly 2001-19 sample, all variables are 
de-trended using the bi-weight kernel-based filter with a five-year window for the kernel, and we use the same three versions of our model based on similar sets of target variables. Inconsistencies in data availability, however, result in some subtle differences relative to our application of the model to China.

For the United States, we use real imports (excluding oil), the headline industrial production diffusion index from the Board of Governors of the Federal Reserve System, and real retail sales (excluding motor vehicle and petrol sales) as target variables. In the case of South Korea, the target variables comprise real imports (including oil), industrial production (in log year-on-year changes, since industrial production diffusion indexes are not available for South Korea), and real retail sales.

Regarding the factor-extraction process, we use the same panel of right-hand side variables for the United States and South Korea as we had for China; these variables were also treated in the same manner with respect to seasonal adjustment and transformations to stationarity. However, because better data are available for the U.S. and South Korean economies, we ended up with more than forty-three variables in most cases (see Appendix 1 for more details). None of these minor data differences should devalue the usefulness of applying our methodology to the United States and South Korea as a robustness check for our China results.

Chart 3 plots, for both the United States and South Korea, the three versions of sparse PLS factor-based estimates of economic activity relative to official year-over-year GDP growth rates. The chart makes clear that these estimates track variations in GDP growth quite accurately for both economies and that the economic activity estimates are less volatile than official GDP growth. In addition, note that in the case of South Korea, targeting more than just real import growth in the factor extraction seems to result in a slightly more accurate tracking of official GDP growth, whereas for the United States, differences between the three approaches are less marked. In summary, applying the same modeling and factor-extraction process to South Korea and the United States generates economic activity estimates that closely track official GDP growth data without being excessively volatile. In fact, for the United States and South Korea, the economic activity estimates are somewhat less volatile and smoother than the official GDP growth data, which is similar to the pattern we observed for China in the pre-2010 period in Chart 1. Given that our estimated economic activity indicators are likely to be less volatile than official GDP growth data when the methodology behind the latter is of reasonably good quality, it would seem that since 2010 China's official GDP figures have become a less dependable gauge of Chinese business cycles. We therefore consider our sparse PLS factor model-based economic activity trackers to be reliable gauges for the strength of economic growth in China.

\subsection{Interpreting the Alternative Indicators}

To better interpret movements in the sparse PLS factor model-based alternative indicators of Chinese economic activity, one could attempt to relate these movements to what are deemed to be relevant shocks for the Chinese economy. In this subsection, we do just that, using version 3 of our sparse PLS factor-based activity indicator, in which the variable selection and factor extraction are done by targeting import growth, the manufacturing production growth diffusion index, and real retail sales growth. Notice from Table 1A in Appendix 1 that real retail sales is not part of the selected variable set for versions 1 and 2 of the sparse factor model, 
Chart 3

Official GDP Growth vs. Alternative Indicators: U.S. and South Korea

— Official GDP

- Version 1

- Version 2

- Version 3

Year-over-year GDP growth, percent

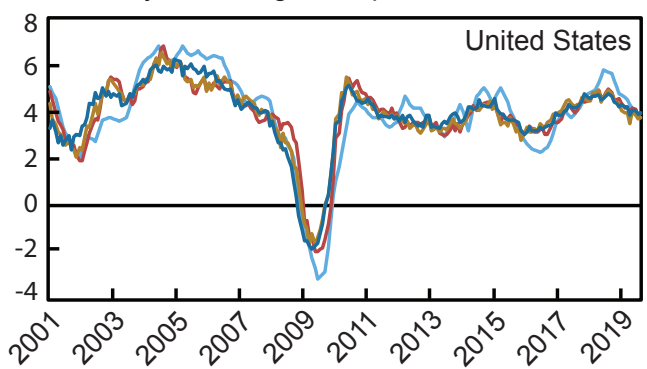

Year-over-year GDP growth, percent

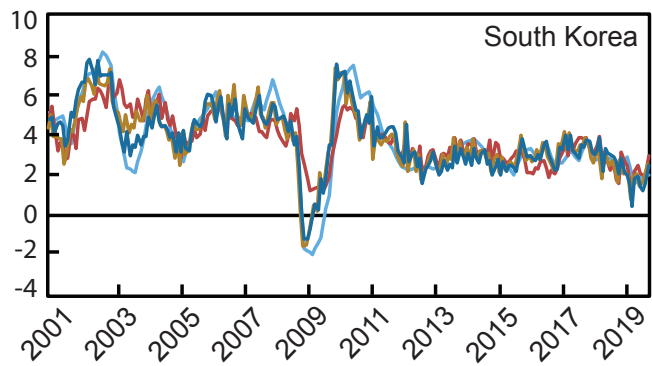

Sources: Authors' calculations; Bank of Korea, accessed through Haver Analytics.

Note: The panels show three versions of the authors' sparse PLS factor model-based activity indicator.

suggesting that including it as a third target variable adds separate, additional information in tracking economic activity in China, particularly with respect to capturing the domestic drivers of the Chinese business cycle more precisely.

Following Bai and $\mathrm{Ng}$ (2007) and Stock and Watson (2012), we posit a vector autoregressive model for the $r$ PLS factors, $f_{t}$, that are estimated by means of SPLS, ${ }^{8}$

$$
\underbrace{f_{t}}_{r \times 1}=\underbrace{D_{0}}_{r \times 1}+\sum_{i=1}^{p} D_{i} \underbrace{f_{t-i}}_{r \times 1}+\underbrace{\varepsilon_{t}}_{r \times 1} ; \quad \varepsilon_{t} \sim \operatorname{iid}\left(\mathbf{0}, \Omega^{\varepsilon}\right) .
$$

As in a standard structural VAR model, restrictions can be placed on the covariance matrix $\Omega^{\varepsilon}$ of the errors in (8) in order to identify a limited number of structural shocks (see also Appendix 2). Therefore, it can be seen from (8), (4), and (3) that different combinations of $r$ (the number of PLS factors, which for version 3 equals 8 ) and $\bar{\lambda}$ (the sparsity parameter) determine in a flexible but parsimonious manner the heterogeneity of the dynamic impact of these identified structural shocks on the retained variables from our initial sample of forty-three activity variables and their correlations with our target variables (real imports, the manufacturing production diffusion index, and real retail sales).

Next, we need to get an idea of the potential number of shocks to underlie the eight factors in version 3 of the sparse PLS factor model-based indicator. Bai and $\mathrm{Ng}$ (2007) propose test procedures that can be used to determine to what degree a VAR model of factors such as (8) has a reduced rank, with the rank being equal to the number of underlying shocks. The procedures, as well as the results of applying them to our case, are described in more detail in Appendix 2, but the tests do suggest that the dynamics in version 3 of the sparse PLS factor model-based indicator seem to be driven by at least three structural shocks. 
To identify these three structural shocks, we need to impose restrictions in the disturbance covariance matrix of VAR model (8), and there are a variety of ways to do this, such as recursive ordering, sign restrictions, and so on. Here we follow Stock and Watson (2012) and Mertens and Ravn (2013), whose approach consists of two steps: First, a VAR model is estimated; then, one or more instrument variable regressions are used to quantify the impact of a shock; this is done by regressing the other VAR residuals on the residual of the VAR equation of the causal variable of interest using an external instrument variable (external in the sense of coming from outside the VAR system) within an instrument variable (IV) regression.

The resulting coefficients measure the impact of the shocks of interest. Their impact beyond the current period can be traced out using the estimated VAR system. In the context of this study, the VAR system is the VAR model in (8) of the PLS factors, and our aim is to quantify up to three shocks - related to global economic activity, Chinese credit supply, and Chinese monetary policy - with three external instrument variables. It is worth noting that in this IV-VAR approach, the IV regression used to determine the structural parameters can be applied to just a subsample of the VAR residuals-if, for example, an external instrument variable is only available for part of the total sample.

The Chinese economy is highly dependent on the state of global economic activity, which can be measured in a number of ways. First, drawing on world trade volume data (2000-present) from the CPB World Trade Monitor, we use the monthly change in the year-over-year growth rate of world trade volume as an instrument for shocks to global economic activity. Another useful gauge in this context is the JP Morgan Global PMI (produced by IHS Markit), which is a GDP-weighted average of monthly outlook surveys for firms in forty-five countries (developed and emerging) that starts in 2004; we use the monthly change in this global PMI as an additional instrument variable for global activity shocks.

The Federal Reserve Bank of New York's weekly Oil Price Dynamics Report provides a third means of identifying global activity shocks. The Report uses correlations between the price of Brent crude oil and an array of financial variables to decompose oil price movements into components related to demand and supply shocks in the global oil market. The third instrument variable for global activity, therefore, is a monthly aggregate of the demand component of oil prices, as identified in the Report, since this metric should reflect market participants' views regarding the global economic outlook.

The first principal component of these three variables-world trade volume growth, the change in the global PMI, and the demand component of oil prices-is then used to aggregate the three instrument variables into a common proxy variable to identify global activity shocks in the PLS VAR model (8), with the corresponding IV regression for the VAR residuals covering a subsample starting in $2004 .^{9}$

Fluctuations in Chinese economic activity could also stem from shifts in domestic monetary policy. Measuring changes in the policy stance of the People's Bank of China (PBoC) is challenging, however, since the $\mathrm{PBoC}$ does not designate a single policy rate as its operating target. Rather, the PBoC uses multiple tools to implement policy: (i) interest rates, such as one-year lending and deposit rates, interest rates on required and excess reserves, and the lending rate on $\mathrm{PBoC}$ refinancing; (ii) quantity-based instruments, such as reserve requirement ratios (RRR) and open market operations (OMO); and (iii) administrative window guidance (a means of influencing bank lending, which is unobserved). Girardin, Lunven, and $\mathrm{Ma}$ (2017) construct a composite policy rate measure that attempts to reflect the changing mix 
of policy instruments utilized by the $\mathrm{PBoC}$ over the 1993-2013 period. This is obviously easier to do for the interest rates under the PBoC's control than for the quantitative instruments it employs. As a result, Girardin, Lunven, and Ma (2017) make a number of assumptions, equating, for example, each 50 basis point change in RRRs to a 27 basis point policy rate change. In the case of OMOs, a monthly net injection or withdrawal of 200 billion yuan in liquidity is converted into a 27 basis point policy rate change, with changes of 350 and 500 billion yuan equivalent to movements of 54 and 81 basis points, respectively. (For more details see Girardin, Lunven, and Ma [2017], Box 1.)

We extend the Girardin, Lunven, and Ma (2017) measure of monthly monetary policy changes, which ends in 2013, to the end of our sample. In doing so, we notice that the volatility and size of the PBoC's OMOs increased drastically after 2015, in line with an increased effort to use OMOs to influence the Chinese seven-day repo rate. Thus, from 2016 onward, we multiplied each of the earlier mentioned threshold sizes of 200, 350, and 500 billion yuan by a factor of 3.6855, in line with the increased volatility of monthly net changes in liquidity during the 2016-19 period. The resulting extended monthly monetary policy change index is then used as a monetary policy instrument variable in the PLS VAR model (8).

As described in Clark, Dawson, and Pinkovskiy (2019), China's economic growth is highly dependent on investment growth, which in turn is primarily financed by loans and other forms of credit. Shocks to the credit supply could therefore be an important driver of the Chinese business cycle. Chinese credit data present a number of difficulties owing to revisions and significant gaps between reported stocks and flows. As a result, Clark, Dawson, and Pinkovskiy (2019) construct a credit stock measure based on reported flows that have more consistent historical series. This adjusted total social financing (TSF) measure includes local currency and FX loans, various forms of off-balance-sheet bank-related lending, nonbank lending (trust loans), and corporate and local government bonds.

This adjusted TSF series is the basis for our credit supply instrument. To strip out demand effects as much as possible, we take the monthly change in the year-over-year growth rate of the adjusted TSF series and regress it on our instrument variables for global economic activity and Chinese monetary policy; the resulting residuals are then used as the credit supply instrument variable in the PLS VAR model (8).

So, if valid, the combination of global activity, credit supply, and monetary policy shocks identified through the IV-VAR approach should explain the bulk of the deviations from trend in the case of the version 3 specification. Chart 4 graphs the resulting decomposition. Unsurprisingly, global economic activity is a dominant driver of fluctuations in Chinese economic activity, with credit supply also a major factor, particularly during boom periods. Monetary policy seems to have had a more profound impact in the pre-2013 era, especially in the post-Great Recession recovery period. When we zoom in on the more recent period beginning with the Great Recession, we notice that up to 2017, slowdowns and accelerations in Chinese growth were led by slowdowns and accelerations in global economic activity, with credit supply mostly supporting growth and Chinese monetary policy having a relatively small, counter-cyclical impact.

From the second half of 2017 onward, however, we observe that credit supply has become the dominant determinant of growth. In addition, since the advent of China's deleveraging campaign in 2018, a slower rate of credit growth has posed a significant drag on growth, and credit supply shocks have recently been somewhat amplified by monetary policy due to a 
Chart 4

Shock Decomposition of the Version 3 Sparse Factor-Based Activity Indicator

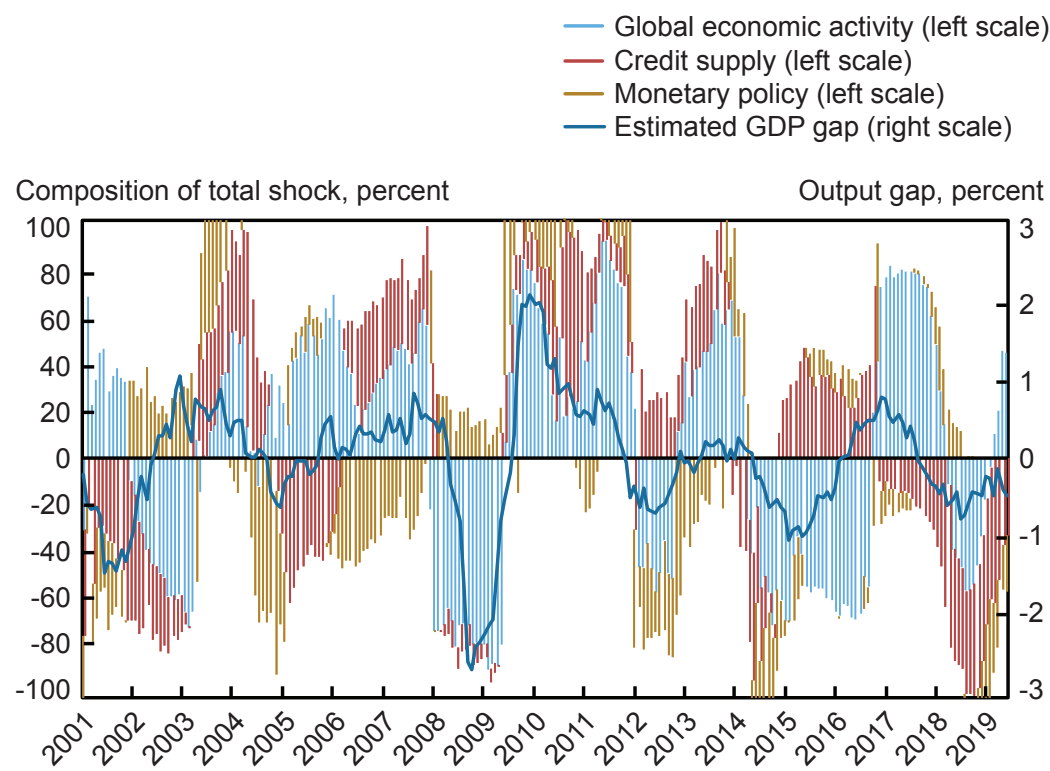

Source: Authors' calculations.

Note: Using version 3 of the sparse PLS factor model-basd activity indicator, the authors decompose deviations from China's trend growth into three components: shocks to global growth, domestic credit supply, and domestic monetary policy.

limited response by the PBoC. Hence, the 2018-19 growth slowdown appears to have been mostly driven by internal rather than external factors-the first such episode of the post-Great Recession era.

\section{Conclusions}

China's official GDP growth rates over the past decade have been remarkably, and perhaps unrealistically, smooth. In an attempt to model Chinese business cycle fluctuations, we created a sparse PLS factor from a large array of high-frequency data. The resulting factor demonstrates the cyclicality expected of China's economic growth, and performs well in out-of-sample testing. For robustness, we tested our model on the United States and South Korea. Our model holds up well, with versions 2 and 3 both providing a good estimate of official GDP growth in each country. Overall, we believe that our sparse PLS model provides an accurate measure of Chinese economic growth at a high frequency.

Focusing on the version of our indicator that conducts variable selection and factor extraction in relation to real import growth, the diffusion index of manufacturing production growth, and real retail sales growth, we decompose the deviation from trend growth into 
global economic activity growth, credit supply, and monetary policy components. We found that global economic activity was the primary driver of Chinese economic activity from the beginning of the Great Recession through 2017. Throughout most of this period, credit supply provided a consistent positive impulse to the economy, while monetary policy had a small and mainly countercyclical effect. Since the beginning of China's deleveraging campaign in 2018, a slowdown in credit supply growth has been a massive drag on the Chinese economy, and monetary policy has posed an additional drag owing to limited PBoC reaction. China's 2018-19 deceleration marks the first time since the beginning of the Great Recession that internal factors, rather than external factors, have been the primary driver of a slowdown in the country's economy. 


\section{Appendix 1: Data Sources And Construction}

The data are retrieved from Haver Analytics and CEIC Data. In order to have $I(0)$ predictor variables, the underlying raw series need to be appropriately transformed.

TABLE $1 \mathrm{~A}$

China

\begin{tabular}{|c|c|c|c|c|c|c|c|}
\hline \multirow[b]{3}{*}{ Variable } & \multirow[b]{3}{*}{ Transformation } & \multicolumn{6}{|c|}{ Economic Activity Indicator } \\
\hline & & \multicolumn{2}{|c|}{ Version 1} & \multicolumn{2}{|c|}{ Version 2} & \multicolumn{2}{|c|}{ Version 3} \\
\hline & & Percent & $\begin{array}{c}\text { Full } \\
\text { Sample }\end{array}$ & Percent & $\begin{array}{c}\text { Full } \\
\text { Sample }\end{array}$ & Percent & $\begin{array}{c}\text { Full } \\
\text { Sample }\end{array}$ \\
\hline Consumer confidence index & SA by X-13, levels & 27 & & 64 & & 63 & $\mathrm{x}$ \\
\hline Consumer expectation index & SA by X-13, levels & 52 & $\mathrm{x}$ & 98 & & 91 & \\
\hline Value-added by industry & SA by $\mathrm{X}-13, \log$ diff & 100 & $\mathrm{x}$ & 100 & $\mathrm{x}$ & 100 & $\mathrm{x}$ \\
\hline Electricity production & SA by $\mathrm{X}-13, \log$ diff & 100 & $\mathrm{x}$ & 100 & $\mathrm{x}$ & 100 & $\mathrm{x}$ \\
\hline Iron ore production & SA by $\mathrm{X}-13, \log$ diff & 100 & $\mathrm{x}$ & 99 & & 100 & $\mathrm{x}$ \\
\hline Pig iron production & SA by $X-13, \log$ diff & 62 & $\mathrm{x}$ & 74 & & 76 & \\
\hline Crude steel production & SA by $\mathrm{X}-13, \log$ diff & 85 & $\mathrm{x}$ & 90 & & 67 & \\
\hline Steel product production & SA by $\mathrm{X}-13, \log$ diff & 51 & $\mathrm{x}$ & 98 & & 84 & \\
\hline Apparent crude demand & SA by X-13, log diff & 15 & & 5 & & 53 & \\
\hline Apparent refined demand & SA by $X-13, \log$ diff & 52 & $\mathrm{x}$ & 70 & & 44 & \\
\hline Copper production & SA by $X-13, \log$ diff & 60 & $\mathrm{x}$ & 69 & & 45 & \\
\hline Aluminum production & SA by $\mathrm{X}-13, \log$ diff & 70 & $\mathrm{x}$ & 99 & & 99 & $\mathrm{x}$ \\
\hline Cement production & SA by $X-13, \log$ diff & 40 & $\mathrm{x}$ & 65 & & 85 & $\mathrm{x}$ \\
\hline Plate glass production & SA by $X-13, \log$ diff & 45 & $\mathrm{x}$ & 29 & & 35 & \\
\hline Real estate investment & SA by $\mathrm{X}-13, \log$ diff & 100 & $\mathrm{x}$ & 99 & & 93 & $\mathrm{x}$ \\
\hline
\end{tabular}




\section{Appendix 1 (Continued)}

\begin{tabular}{|c|c|c|c|c|c|c|c|}
\hline \multirow[b]{3}{*}{ Variable } & \multirow[b]{3}{*}{ Transformation } & \multicolumn{6}{|c|}{ Economic Activity Indicator } \\
\hline & & \multicolumn{2}{|c|}{ Version 1} & \multicolumn{2}{|c|}{ Version 2} & \multicolumn{2}{|c|}{ Version 3} \\
\hline & & Percent & $\begin{array}{c}\text { Full } \\
\text { Sample }\end{array}$ & Percent & $\begin{array}{c}\text { Full } \\
\text { Sample }\end{array}$ & Percent & $\begin{array}{c}\text { Full } \\
\text { Sample }\end{array}$ \\
\hline Floor space started & SA by $X-13, \log$ diff & 33 & $\mathrm{x}$ & 54 & & 52 & \\
\hline $\begin{array}{l}\text { Floor space under } \\
\text { construction (residential) }\end{array}$ & SA by $X-13, \log$ diff & 100 & $\mathrm{x}$ & 98 & & 100 & $\mathrm{x}$ \\
\hline Floor space completed & SA by X-13, log diff & 91 & $\mathrm{x}$ & 78 & & 47 & \\
\hline Floor space sold & SA by $\mathrm{X}-13, \log$ diff & 45 & & 53 & & 67 & \\
\hline Imports of iron ore (volume) & SA by $\mathrm{X}-13, \log$ diff & 54 & & 41 & & 82 & $\mathrm{x}$ \\
\hline $\begin{array}{l}\text { Steel product imports } \\
\text { (volume) }\end{array}$ & SA by $X-13, \log$ diff & 67 & $\mathrm{x}$ & 94 & & 74 & \\
\hline Imports of unwrought copper & SA by $X-13, \log$ diff & 68 & $\mathrm{x}$ & 43 & & 47 & $\mathrm{x}$ \\
\hline Imports of copper waste & SA by $\mathrm{X}-13, \log$ diff & 100 & $\mathrm{x}$ & 87 & & 77 & $\mathrm{x}$ \\
\hline $\begin{array}{l}\text { Imports of unwrought } \\
\text { aluminium }\end{array}$ & SA by X-13, log diff & 100 & $\mathrm{x}$ & 97 & & 93 & $\mathrm{x}$ \\
\hline Steel products exports & SA by X-13, log diff & 48 & $\mathrm{x}$ & 80 & & 62 & $\mathrm{x}$ \\
\hline $\begin{array}{l}\text { Unwrought copper export } \\
\text { volume }\end{array}$ & SA by $X-13, \log$ diff & 74 & & 54 & & 82 & \\
\hline $\begin{array}{l}\text { Unwrought aluminum } \\
\text { export volume }\end{array}$ & SA by $X-13, \log$ diff & 34 & $\mathrm{x}$ & 82 & & 64 & \\
\hline $\begin{array}{l}\text { Nominal fixed asset } \\
\text { investment }\end{array}$ & SA by $X-13, \log$ diff & 84 & & 62 & & 70 & \\
\hline Auto sales & SA by X-13, log diff & 100 & $\mathrm{x}$ & 100 & $\mathrm{x}$ & 97 & $\mathrm{x}$ \\
\hline Rail freight & SA by $X-13, \log$ diff & 86 & & 88 & & 85 & \\
\hline Air pass-through & SA by $X-13, \log$ diff & 46 & $\mathrm{x}$ & 93 & & 60 & \\
\hline Petrol imports & SA by $X-13, \log$ diff & 92 & $\mathrm{x}$ & 99 & & 91 & $\mathrm{x}$ \\
\hline
\end{tabular}




\section{Appendix 1 (Continued)}

\begin{tabular}{|c|c|c|c|c|c|c|c|}
\hline \multirow[b]{3}{*}{ Variable } & \multirow[b]{3}{*}{ Transformation } & \multicolumn{6}{|c|}{ Economic Activity Indicator } \\
\hline & & \multicolumn{2}{|c|}{ Version 1} & \multicolumn{2}{|c|}{ Version 2} & \multicolumn{2}{|c|}{ Version 3} \\
\hline & & Percent & $\begin{array}{l}\text { Full } \\
\text { Sample }\end{array}$ & Percent & $\begin{array}{c}\text { Full } \\
\text { Sample }\end{array}$ & Percent & $\begin{array}{l}\text { Full } \\
\text { Sample }\end{array}$ \\
\hline Foreign reserves & Log diff & 60 & & 97 & & 84 & $\mathrm{x}$ \\
\hline Exchange rate (U.S. dollar) & Log diff & 26 & $\mathrm{x}$ & 33 & & 70 & \\
\hline $\begin{array}{l}\text { Shanghai Stock } \\
\text { Exchange index }\end{array}$ & Log diff & 81 & & 53 & & 90 & $\mathrm{x}$ \\
\hline $\begin{array}{l}\text { Shenzhen Stock } \\
\text { Exchange index }\end{array}$ & Log diff & 73 & & 62 & & 85 & $\mathrm{x}$ \\
\hline $\begin{array}{l}\text { Price/equity ratio for } \\
\text { Shanghai Stock Exchange }\end{array}$ & Log diff & 94 & $\mathrm{x}$ & 95 & & 93 & $\mathrm{x}$ \\
\hline $\begin{array}{l}\text { Price/equity ration for } \\
\text { Shenzhen Stock Exchange }\end{array}$ & Log diff & 80 & & 86 & & 92 & $\mathrm{x}$ \\
\hline Producer price index & SA by $X-13, \log$ diff & 100 & $\mathrm{x}$ & 100 & $\mathrm{x}$ & 97 & $\mathrm{x}$ \\
\hline Consumer price index & SA by $X-13, \log$ diff & 73 & $\mathrm{x}$ & 82 & & 98 & $\mathrm{x}$ \\
\hline Seven-day repo rate & Levels & 12 & & 46 & & 61 & \\
\hline M1 & SA by $X-13, \log$ diff & 67 & $\mathrm{x}$ & 78 & & 64 & $\mathrm{x}$ \\
\hline M2 & SA by $X-13, \log$ diff & 65 & & 98 & & 95 & \\
\hline Real retail sales & SA by X-13, log diff & 98 & & 59 & & 0 & \\
\hline
\end{tabular}

Notes: In the "Transformation" column, "SA" stands for "seasonally adjusted;" "X-13" is the U.S. Census Bureau's seasonal adjustment methodology; and "log diff" refers to the following transformation: $X_{t}=\ln \left(Y_{t}\right)-\ln \left(Y_{t-12}\right)$, with $X_{t}$ being the transformed variable and $Y_{t}$ being the raw variable. "Percent" denotes the percentage of out-of-sample and full-sample model estimations in which the variable was not dropped. Variables that were not dropped in the full-sample estimation are marked by an $\mathrm{x}$ in the "full-sample" column. 


\section{AppendiX 1 (Continued)}

TABLE 1B

United States

\begin{tabular}{|c|c|c|c|c|c|c|c|}
\hline \multirow[b]{3}{*}{ Variable } & \multirow[b]{3}{*}{ Transformation } & \multicolumn{6}{|c|}{ Economic Activity Indicator } \\
\hline & & \multicolumn{2}{|c|}{ Version 1} & \multicolumn{2}{|c|}{ Version 2} & \multicolumn{2}{|c|}{ Version 3} \\
\hline & & Percent & $\begin{array}{c}\text { Full } \\
\text { Sample }\end{array}$ & Percent & $\begin{array}{c}\text { Full } \\
\text { Sample }\end{array}$ & Percent & $\begin{array}{c}\text { Full } \\
\text { Sample }\end{array}$ \\
\hline $\begin{array}{l}\text { Nominal trade-weighted } \\
\text { exchange rate for emerging } \\
\text { market economies } \\
\text { (Federal Reserve Board) }\end{array}$ & Log diff & 79 & $\mathrm{x}$ & 82 & $\mathrm{x}$ & 49 & \\
\hline M2 & Log diff & 97 & $\mathrm{x}$ & 24 & $\mathrm{x}$ & 82 & $\mathrm{x}$ \\
\hline Ratio of nominal GDP to M2 & SA by Haver, Levels & 26 & & 32 & $\mathrm{x}$ & 23 & \\
\hline Consumer credit & $\begin{array}{l}\text { SA by source, } \\
\text { log diff }\end{array}$ & 93 & $\mathrm{x}$ & 100 & $\mathrm{x}$ & 32 & $\mathrm{x}$ \\
\hline $\begin{array}{l}\text { Commercial banks' } \\
\text { loan-to-deposit ratio }\end{array}$ & SA by Haver & 28 & & 72 & $\mathrm{x}$ & 100 & $\mathrm{x}$ \\
\hline $\begin{array}{l}\text { Fixed rate home mortgage } \\
\text { loans: Effective rate }\end{array}$ & Levels & 94 & $\mathrm{x}$ & 2 & $\mathrm{x}$ & 71 & \\
\hline Dow 30: Average close & Log diff & 4 & $\mathrm{x}$ & 3 & & 1 & \\
\hline $\begin{array}{l}\text { Standard \& Poor's } 500 \\
\text { composite index }\end{array}$ & Log diff & 5 & $\mathrm{x}$ & 11 & & 3 & \\
\hline NASDAQ Composite Index & Log diff & 20 & & 7 & & 11 & \\
\hline NYSE Composite Index & Log diff & 48 & $\mathrm{x}$ & 10 & $\mathrm{x}$ & 7 & \\
\hline $\begin{array}{l}\text { Federal Housing Finance } \\
\text { Agency House Price Index: } \\
\text { Purchases only }\end{array}$ & $\begin{array}{l}\text { SA by source, } \\
\text { log diff }\end{array}$ & 98 & $\mathrm{x}$ & 4 & & 9 & \\
\hline Housing starts & $\begin{array}{l}\text { SA by source, } \\
\text { log diff }\end{array}$ & 53 & $\mathrm{x}$ & 4 & & 4 & \\
\hline Housing completions & $\begin{array}{l}\text { SA by source, } \\
\text { log diff }\end{array}$ & 53 & $\mathrm{x}$ & 30 & $\mathrm{x}$ & 4 & \\
\hline $\begin{array}{l}\text { Industrial production: } \\
\text { Automotive products }\end{array}$ & $\begin{array}{l}\text { SA by source, } \\
\text { log diff }\end{array}$ & 0 & & 80 & $\mathrm{x}$ & 29 & \\
\hline $\begin{array}{l}\text { Industrial production: } \\
\text { Consumer goods }\end{array}$ & $\begin{array}{l}\text { SA by source, } \\
\text { log diff }\end{array}$ & 90 & $\mathrm{x}$ & 100 & $\mathrm{x}$ & 80 & $\mathrm{x}$ \\
\hline
\end{tabular}




\section{Appendix 1 (Continued)}

\begin{tabular}{|c|c|c|c|c|c|c|c|}
\hline \multirow[b]{3}{*}{ Variable } & \multirow[b]{3}{*}{ Transformation } & \multicolumn{6}{|c|}{ Economic Activity Indicator } \\
\hline & & \multicolumn{2}{|c|}{ Version 1} & \multicolumn{2}{|c|}{ Version 2} & \multicolumn{2}{|c|}{ Version 3} \\
\hline & & Percent & $\begin{array}{c}\text { Full } \\
\text { Sample }\end{array}$ & Percent & $\begin{array}{c}\text { Full } \\
\text { Sample }\end{array}$ & Percent & $\begin{array}{c}\text { Full } \\
\text { Sample }\end{array}$ \\
\hline $\begin{array}{l}\text { Industrial production: } \\
\text { Business equipment }\end{array}$ & $\begin{array}{l}\text { SA by source, } \\
\text { log diff }\end{array}$ & 100 & $\mathrm{x}$ & 100 & $\mathrm{x}$ & 100 & $\mathrm{x}$ \\
\hline $\begin{array}{l}\text { Industrial production: } \\
\text { Durable goods materials }\end{array}$ & $\begin{array}{l}\text { SA by source, } \\
\text { log diff }\end{array}$ & 100 & $\mathrm{x}$ & 97 & $\mathrm{x}$ & 100 & $\mathrm{x}$ \\
\hline $\begin{array}{l}\text { Industrial production: } \\
\text { Nondurable goods materials }\end{array}$ & $\begin{array}{l}\text { SA by source, } \\
\text { log diff }\end{array}$ & 58 & $\mathrm{x}$ & 6 & $\mathrm{x}$ & 96 & \\
\hline $\begin{array}{l}\text { Industrial production: } \\
\text { Energy materials }\end{array}$ & $\begin{array}{l}\text { SA by source, } \\
\text { log diff }\end{array}$ & 9 & & 30 & $\mathrm{x}$ & 5 & \\
\hline $\begin{array}{l}\text { Civilian unemployment rate } \\
\text { (aged } 16+\text { ) }\end{array}$ & $\begin{array}{l}\text { SA by source, } \\
\text { levels }\end{array}$ & 16 & $\mathrm{x}$ & 63 & $\mathrm{x}$ & 29 & \\
\hline $\begin{array}{l}\text { Manufacturers' shipments: } \\
\text { Machinery }\end{array}$ & $\begin{array}{l}\text { SA by source, } \\
\text { log diff }\end{array}$ & 97 & $\mathrm{x}$ & 100 & $\mathrm{x}$ & 62 & \\
\hline $\begin{array}{l}\text { Manufacturers' shipments: } \\
\text { Primary metals }\end{array}$ & $\begin{array}{l}\text { SA by source, } \\
\text { log diff }\end{array}$ & 100 & $\mathrm{x}$ & 10 & $\mathrm{x}$ & 100 & $\mathrm{x}$ \\
\hline $\begin{array}{l}\text { Manufacturers' shipments: } \\
\text { Computers and electronic } \\
\text { products }\end{array}$ & $\begin{array}{l}\text { SA by source, } \\
\text { log diff }\end{array}$ & 96 & $\mathrm{x}$ & 88 & & 9 & \\
\hline $\begin{array}{l}\text { Manufacturers' shipments: } \\
\text { Electronic equipment, } \\
\text { appliances, and components }\end{array}$ & $\begin{array}{l}\text { SA by source, } \\
\text { log diff }\end{array}$ & 100 & $\mathrm{x}$ & 76 & $\mathrm{x}$ & 88 & \\
\hline $\begin{array}{l}\text { Manufacturers' shipments: } \\
\text { Transportation equipment }\end{array}$ & $\begin{array}{l}\text { SA by source, } \\
\text { log diff }\end{array}$ & 82 & $\mathrm{x}$ & 11 & $\mathrm{x}$ & 75 & \\
\hline $\begin{array}{l}\text { Manufacturers' shipments: } \\
\text { Food products }\end{array}$ & $\begin{array}{l}\text { SA by source, } \\
\text { log diff }\end{array}$ & 96 & $\mathrm{x}$ & 2 & $\mathrm{x}$ & 10 & \\
\hline $\begin{array}{l}\text { Manufacturers' shipments: } \\
\text { Textile products }\end{array}$ & $\begin{array}{l}\text { SA by source, } \\
\text { log diff }\end{array}$ & 20 & & 15 & $\mathrm{x}$ & 1 & \\
\hline $\begin{array}{l}\text { Manufacturers' shipments: } \\
\text { Paper products }\end{array}$ & $\begin{array}{l}\text { SA by source, } \\
\text { log diff }\end{array}$ & 96 & $\mathrm{x}$ & 70 & & 14 & \\
\hline $\begin{array}{l}\text { Manufacturers' shipments: } \\
\text { Petroleum and coal products }\end{array}$ & $\begin{array}{l}\text { SA by source, } \\
\text { log diff }\end{array}$ & 63 & $\mathrm{x}$ & 100 & $\mathrm{x}$ & 70 & \\
\hline $\begin{array}{l}\text { Manufacturers' shipments: } \\
\text { Basic chemicals }\end{array}$ & $\begin{array}{l}\text { SA by source, } \\
\text { log diff }\end{array}$ & 100 & $\mathrm{x}$ & 97 & $\mathrm{x}$ & 100 & $\mathrm{x}$ \\
\hline
\end{tabular}




\section{Appendix 1 (Continued)}

\begin{tabular}{|c|c|c|c|c|c|c|c|}
\hline \multirow[b]{3}{*}{ Variable } & \multirow[b]{3}{*}{ Transformation } & \multicolumn{6}{|c|}{ Economic Activity Indicator } \\
\hline & & \multicolumn{2}{|c|}{ Version 1} & \multicolumn{2}{|c|}{ Version 2} & \multicolumn{2}{|c|}{ Version 3} \\
\hline & & Percent & $\begin{array}{c}\text { Full } \\
\text { Sample }\end{array}$ & Percent & $\begin{array}{c}\text { Full } \\
\text { Sample }\end{array}$ & Percent & $\begin{array}{c}\text { Full } \\
\text { Sample }\end{array}$ \\
\hline $\begin{array}{l}\text { Manufacturers' new orders: } \\
\text { All manufacturing } \\
\text { (ex defense) }\end{array}$ & $\begin{array}{l}\text { SA by source, } \\
\text { log diff }\end{array}$ & 100 & $\mathrm{x}$ & 12 & $\mathrm{x}$ & 100 & $\mathrm{x}$ \\
\hline $\begin{array}{l}\text { Manufacturers' inventories: } \\
\text { All manufacturing } \\
\text { (ex defense) }\end{array}$ & $\begin{array}{l}\text { SA by source, } \\
\text { log diff }\end{array}$ & 95 & $\mathrm{x}$ & 98 & & 11 & \\
\hline $\begin{array}{l}\text { Manufacturers' shipments: } \\
\text { Construction materials } \\
\text { and supplies }\end{array}$ & $\begin{array}{l}\text { SA by source, } \\
\text { log diff }\end{array}$ & 100 & $\mathrm{x}$ & 2 & $\mathrm{x}$ & 99 & $\mathrm{x}$ \\
\hline $\begin{array}{l}\text { Manufacturers' shipments: } \\
\text { Information technology }\end{array}$ & $\begin{array}{l}\text { SA by source, } \\
\text { log diff }\end{array}$ & 59 & $\mathrm{x}$ & 21 & & 1 & \\
\hline $\begin{array}{l}\text { Manufacturers' shipments: } \\
\text { Capital goods }\end{array}$ & $\begin{array}{l}\text { SA by source, } \\
\text { log diff }\end{array}$ & 96 & $\mathrm{x}$ & 24 & & 21 & \\
\hline $\begin{array}{l}\text { Manufacturers' shipments: } \\
\text { Consumer goods }\end{array}$ & $\begin{array}{l}\text { SA by source, } \\
\text { log diff }\end{array}$ & 97 & $\mathrm{x}$ & 82 & & 24 & \\
\hline $\begin{array}{l}\text { Average weekly hours: } \\
\text { Manufacturing }\end{array}$ & $\begin{array}{l}\text { SA by source, } \\
\text { log diff }\end{array}$ & 55 & $\mathrm{x}$ & 19 & $\mathrm{x}$ & 82 & \\
\hline Real M2 & $\begin{array}{l}\text { SA by source, } \\
\text { log diff }\end{array}$ & 95 & $\mathrm{x}$ & 69 & & 18 & \\
\hline $\begin{array}{l}\text { Real personal income } \\
\text { (less transfer payments) }\end{array}$ & $\begin{array}{l}\text { SA by source, } \\
\text { log diff }\end{array}$ & 88 & $\mathrm{x}$ & 99 & & 70 & $\mathrm{x}$ \\
\hline Industrial production & $\begin{array}{l}\text { SA by source, } \\
\text { log diff }\end{array}$ & 100 & $\mathrm{x}$ & 7 & $\mathrm{x}$ & 100 & $\mathrm{x}$ \\
\hline Total nonfarm employees & $\begin{array}{l}\text { SA by source, } \\
\text { log diff }\end{array}$ & 96 & $\mathrm{x}$ & 100 & $\mathrm{x}$ & 7 & $\mathrm{x}$ \\
\hline $\begin{array}{l}\text { Real manufacturing and } \\
\text { trade sales }\end{array}$ & $\begin{array}{l}\text { SA by source, } \\
\text { log diff }\end{array}$ & 96 & $\mathrm{x}$ & 10 & $\mathrm{x}$ & 100 & $\mathrm{x}$ \\
\hline $\begin{array}{l}\text { Average duration of } \\
\text { unemployment }\end{array}$ & $\begin{array}{l}\text { SA by source, } \\
\text { log diff }\end{array}$ & 25 & $\mathrm{x}$ & 99 & & 10 & $\mathrm{x}$ \\
\hline $\begin{array}{l}\text { Real manufacturing and } \\
\text { trade: Inventories/sales }\end{array}$ & $\begin{array}{l}\text { SA by source, } \\
\text { log diff }\end{array}$ & 51 & $\mathrm{x}$ & 9 & $\mathrm{x}$ & 100 & $\mathrm{x}$ \\
\hline Bank prime loan rate & Levels & 89 & $\mathrm{x}$ & 79 & & 8 & \\
\hline
\end{tabular}




\section{Appendix 1 (Continued)}

\begin{tabular}{|c|c|c|c|c|c|c|c|}
\hline \multirow[b]{3}{*}{ Variable } & \multirow[b]{3}{*}{ Transformation } & \multicolumn{6}{|c|}{ Economic Activity Indicator } \\
\hline & & \multicolumn{2}{|c|}{ Version 1} & \multicolumn{2}{|c|}{ Version 2} & \multicolumn{2}{|c|}{ Version 3} \\
\hline & & Percent & $\begin{array}{l}\text { Full } \\
\text { Sample }\end{array}$ & Percent & $\begin{array}{c}\text { Full } \\
\text { Sample }\end{array}$ & Percent & $\begin{array}{l}\text { Full } \\
\text { Sample }\end{array}$ \\
\hline $\begin{array}{l}\text { Real commercial and } \\
\text { industrial loans } \\
\text { outstanding }\end{array}$ & $\begin{array}{l}\text { SA by source, } \\
\log \text { diff }\end{array}$ & 73 & $\mathrm{x}$ & 95 & $\mathrm{x}$ & 79 & \\
\hline $\begin{array}{l}\text { Ratio of consumer credit } \\
\text { to personal income }\end{array}$ & SA by source, levels & 100 & $\mathrm{x}$ & 7 & $\mathrm{x}$ & 94 & \\
\hline $\begin{array}{l}\text { CPI for services: Six-month } \\
\text { change }\end{array}$ & $\begin{array}{l}\text { SAAR (percent) } \\
\text { by source }\end{array}$ & 89 & $\mathrm{x}$ & 48 & & 6 & \\
\hline $\begin{array}{l}\text { Conference Board: Consumer } \\
\text { Confidence Index }\end{array}$ & SA by source, levels & 100 & $\mathrm{x}$ & 92 & $\mathrm{x}$ & 49 & $\mathrm{x}$ \\
\hline $\begin{array}{l}\text { Conference Board: Consumer } \\
\text { Expectations Index }\end{array}$ & SA by source, levels & 31 & $\mathrm{x}$ & 16 & $\mathrm{x}$ & 91 & \\
\hline ISM Composite Index & SA by source, levels & 9 & $\mathrm{x}$ & 0 & & 15 & \\
\hline
\end{tabular}

Notes: In the "Transformation" column, "SA" stands for "seasonally adjusted;" "SAAR" stands for "seasonally adjusted annualized rate;" "Haver" refers to "Haver Analytics;" and "log diff" refers to the following transformation: $X_{t}=\ln \left(Y_{t}\right)-\ln \left(Y_{t-12}\right)$, with $X_{t}$ being the transformed variable and $Y_{t}$ being the raw variable. "Percent" denotes the percentage of out-of-sample and full-sample model estimations in which the variable was not dropped. Variables that were not dropped in the full-sample estimation are marked by an $\mathrm{x}$ in the "full-sample" column. 


\section{Appendix 1 (Continued)}

TABle $1 \mathrm{C}$

South Korea

\begin{tabular}{|c|c|c|c|c|c|c|c|}
\hline \multirow[b]{3}{*}{ Variable } & \multirow[b]{3}{*}{ Transformation } & \multicolumn{6}{|c|}{ Economic Activity Indicator } \\
\hline & & \multicolumn{2}{|c|}{ Version 1} & \multicolumn{2}{|c|}{ Version 2} & \multicolumn{2}{|c|}{ Version 3} \\
\hline & & Percent & $\begin{array}{c}\text { Full } \\
\text { Sample }\end{array}$ & Percent & $\begin{array}{c}\text { Full } \\
\text { Sample }\end{array}$ & Percent & $\begin{array}{c}\text { Full } \\
\text { Sample }\end{array}$ \\
\hline Bank of Korea Base Rate & Levels & 36 & & 78 & $\mathrm{x}$ & 64 & $\mathrm{x}$ \\
\hline $\begin{array}{l}\text { Ninety-one-day } \\
\text { commercial paper yields }\end{array}$ & Levels & 99 & $\mathrm{x}$ & 78 & $\mathrm{x}$ & 64 & $\mathrm{x}$ \\
\hline $\begin{array}{l}\text { Exchange rate } \\
\text { (won/U.S. dollar) }\end{array}$ & Log diff & 75 & & 3 & $\mathrm{x}$ & 48 & $\mathrm{x}$ \\
\hline Reserve money & SA by source, log diff & 18 & & 0 & & 24 & \\
\hline M2 & SA by source, log diff & 8 & & 13 & $\mathrm{x}$ & 54 & \\
\hline Bank of Korea assets & SA by Haver, log diff & 35 & & 29 & $\mathrm{x}$ & 89 & $\mathrm{x}$ \\
\hline $\begin{array}{l}\text { Depository corporation } \\
\text { assets }\end{array}$ & SA by Haver, log diff & 100 & $\mathrm{x}$ & 81 & $\mathrm{x}$ & 67 & $\mathrm{x}$ \\
\hline $\begin{array}{l}\text { Depository corporation } \\
\text { liabilities and capital }\end{array}$ & SA by Haver, log diff & 100 & $\mathrm{x}$ & 81 & $\mathrm{x}$ & 67 & $\mathrm{x}$ \\
\hline $\begin{array}{l}\text { Deposit Money Banks: } \\
\text { Loans }\end{array}$ & $\begin{array}{l}\text { SA by Haver, } \\
\text { log diff }\end{array}$ & 96 & $\mathrm{x}$ & 44 & $\mathrm{x}$ & 71 & $\mathrm{x}$ \\
\hline $\begin{array}{l}\text { Other Depository Corps } \\
\text { Loan to Deposit Ratio }\end{array}$ & $\begin{array}{l}\text { SA by Haver, } \\
\text { levels }\end{array}$ & 44 & & 4 & $\mathrm{x}$ & 99 & $\mathrm{x}$ \\
\hline $\begin{array}{l}\text { Central bank deposits of } \\
\text { commercial banks and } \\
\text { savings banks }\end{array}$ & $\begin{array}{l}\text { SA by Haver, } \\
\text { log diff }\end{array}$ & 14 & & 3 & & 53 & $\mathrm{x}$ \\
\hline Stock price index: KOSPI & Log diff & 80 & & 4 & $\mathrm{x}$ & 85 & $\mathrm{x}$ \\
\hline Stock price index: KOSDAQ & Log diff & 77 & & 10 & & 85 & $\mathrm{x}$ \\
\hline $\begin{array}{l}\text { Stock exchange market } \\
\text { cap (won) }\end{array}$ & Log diff & 99 & $\mathrm{x}$ & 43 & & 62 & $\mathrm{x}$ \\
\hline $\begin{array}{l}\text { Stock exchange market } \\
\text { cap (U.S. dollars) }\end{array}$ & Log diff & 95 & $\mathrm{x}$ & 7 & $\mathrm{x}$ & 54 & $\mathrm{x}$ \\
\hline $\begin{array}{l}\text { MSCI Korea Index, ex } \\
\text { dividends (U.S. dollars) }\end{array}$ & Log diff & 47 & & 37 & $\mathrm{x}$ & 60 & $\mathrm{x}$ \\
\hline
\end{tabular}




\section{ApPENDiX 1 (Continued)}

\begin{tabular}{|c|c|c|c|c|c|c|c|}
\hline \multirow[b]{3}{*}{ Variable } & \multirow[b]{3}{*}{ Transformation } & \multicolumn{6}{|c|}{ Economic Activity Indicator } \\
\hline & & \multicolumn{2}{|c|}{ Version 1} & \multicolumn{2}{|c|}{ Version 2} & \multicolumn{2}{|c|}{ Version 3} \\
\hline & & Percent & $\begin{array}{c}\text { Full } \\
\text { Sample }\end{array}$ & Percent & $\begin{array}{c}\text { Full } \\
\text { Sample }\end{array}$ & Percent & $\begin{array}{c}\text { Full } \\
\text { Sample }\end{array}$ \\
\hline $\begin{array}{l}\text { MSCI Korea Index, ex } \\
\text { dividends (won) }\end{array}$ & Log diff & 34 & & 3 & $\mathrm{x}$ & 62 & $\mathrm{x}$ \\
\hline $\begin{array}{l}\text { MSCI Korea Index, with } \\
\text { gross dividends } \\
\text { (U.S. dollars) }\end{array}$ & Log diff & 48 & & 37 & $\mathrm{x}$ & 60 & $\mathrm{x}$ \\
\hline $\begin{array}{l}\text { MSCI Korea Index, with } \\
\text { gross dividends (won) }\end{array}$ & Log diff & 38 & & 3 & $\mathrm{x}$ & 61 & $\mathrm{x}$ \\
\hline $\begin{array}{l}\text { Number of listed issues: } \\
\text { Bonds }\end{array}$ & Log diff & 100 & $\mathrm{x}$ & 64 & $\mathrm{x}$ & 55 & $\mathrm{x}$ \\
\hline Listed issues: Public bonds & Log diff & 34 & & 2 & $\mathrm{x}$ & 37 & \\
\hline $\begin{array}{l}\text { Listed issues: Corporate } \\
\text { bonds }\end{array}$ & Log diff & 86 & $\mathrm{x}$ & 27 & $\mathrm{x}$ & 87 & $\mathrm{x}$ \\
\hline $\begin{array}{l}\text { Trading volume: Corporate } \\
\text { bonds }\end{array}$ & Log diff & 90 & $\mathrm{x}$ & 77 & $\mathrm{x}$ & 65 & $\mathrm{x}$ \\
\hline Trading value: Bonds & Log diff & 1 & & 0 & & 36 & \\
\hline Trading value: Public bonds & Log diff & 2 & & 0 & & 35 & \\
\hline $\begin{array}{l}\text { Trading value: Corporate } \\
\text { bonds }\end{array}$ & Log diff & 80 & $\mathrm{x}$ & 97 & $\mathrm{x}$ & 92 & $\mathrm{x}$ \\
\hline $\begin{array}{l}\text { Foreign exchange holdings } \\
\text { (gold and special drawing } \\
\text { rights) }\end{array}$ & SA by Haver, log diff & 15 & & 2 & & 45 & $\mathrm{x}$ \\
\hline $\begin{array}{l}\text { International liquidity } \\
\text { reserves (minus gold) }\end{array}$ & SA by Haver, log diff & 15 & & 2 & & 44 & $\mathrm{x}$ \\
\hline $\begin{array}{l}\text { CPI (ex agricultural } \\
\text { products and oil) }\end{array}$ & SA by source, log diff & 19 & & 7 & & 67 & $\mathrm{x}$ \\
\hline CPI: All & SA by source, log diff & 100 & $\mathrm{x}$ & 56 & $\mathrm{x}$ & 93 & $\mathrm{x}$ \\
\hline $\begin{array}{l}\text { CPI: Agricultural products } \\
\text { and oil }\end{array}$ & SA by source, log diff & 20 & & 4 & & 34 & $\mathrm{x}$ \\
\hline
\end{tabular}




\section{Appendix 1 (Continued)}

\begin{tabular}{|c|c|c|c|c|c|c|c|}
\hline \multirow[b]{3}{*}{ Variable } & \multirow[b]{3}{*}{ Transformation } & \multicolumn{6}{|c|}{ Economic Activity Indicator } \\
\hline & & \multicolumn{2}{|c|}{ Version 1} & \multicolumn{2}{|c|}{ Version 2} & \multicolumn{2}{|c|}{ Version 3} \\
\hline & & Percent & $\begin{array}{c}\text { Full } \\
\text { Sample }\end{array}$ & Percent & $\begin{array}{c}\text { Full } \\
\text { Sample }\end{array}$ & Percent & $\begin{array}{c}\text { Full } \\
\text { Sample }\end{array}$ \\
\hline CPI: Industrial Products & SA by Haver, log diff & 24 & & 11 & $\mathrm{x}$ & 96 & $\mathrm{x}$ \\
\hline CPI: Services & SA by Haver, log diff & 11 & & 11 & $\mathrm{x}$ & 28 & $\mathrm{x}$ \\
\hline PPI & SA by source, log diff & 30 & & 49 & $\mathrm{x}$ & 85 & $\mathrm{x}$ \\
\hline PPI: Commodities & SA by source, log diff & 21 & & 41 & $\mathrm{x}$ & 81 & $\mathrm{x}$ \\
\hline PPI: Manufacturing & SA by source, log diff & 25 & & 47 & $\mathrm{x}$ & 85 & $\mathrm{x}$ \\
\hline PPI: Mining & SA by source, log diff & 33 & $\mathrm{x}$ & 29 & $\mathrm{x}$ & 92 & $\mathrm{x}$ \\
\hline PPI: Services & SA by source, log diff & 100 & $\mathrm{x}$ & 100 & $\mathrm{x}$ & 98 & $\mathrm{x}$ \\
\hline Unleaded gasoline price & SA by Haver, log diff & 35 & & 5 & $\mathrm{x}$ & 37 & $\mathrm{x}$ \\
\hline $\begin{array}{l}\text { House purchase price } \\
\text { composite index }\end{array}$ & SA by Haver, log diff & 92 & $\mathrm{x}$ & 53 & $\mathrm{x}$ & 92 & $\mathrm{x}$ \\
\hline $\begin{array}{l}\text { Apartment purchase } \\
\text { price index }\end{array}$ & SA by Haver, log diff & 36 & & 54 & $\mathrm{x}$ & 89 & $\mathrm{x}$ \\
\hline Building permits: Square feet & SA by source, log diff & 7 & & 7 & & 20 & \\
\hline Building permits: Units & SA by source, log diff & 19 & & 0 & & 48 & $\mathrm{x}$ \\
\hline $\begin{array}{l}\text { Industrial production, ex } \\
\text { construction }\end{array}$ & SA by source, log diff & 100 & $\mathrm{x}$ & 100 & $\mathrm{x}$ & 100 & $\mathrm{x}$ \\
\hline $\begin{array}{l}\text { Industrial production: } \\
\text { Mining and manufacturing }\end{array}$ & SA by source, log diff & 100 & $\mathrm{x}$ & 100 & $\mathrm{x}$ & 100 & $\mathrm{x}$ \\
\hline $\begin{array}{l}\text { Inudstrial production: } \\
\text { Construction }\end{array}$ & SA by source, log diff & 11 & & 100 & $\mathrm{x}$ & 97 & $\mathrm{x}$ \\
\hline $\begin{array}{l}\text { Industrial production: } \\
\text { Services }\end{array}$ & SA by source, log diff & 81 & $\mathrm{x}$ & 100 & $\mathrm{x}$ & 100 & $\mathrm{x}$ \\
\hline $\begin{array}{l}\text { Industrial production: } \\
\text { Public admin }\end{array}$ & SA by source, log diff & 70 & $\mathrm{x}$ & 100 & $\mathrm{X}$ & 96 & $\mathrm{x}$ \\
\hline
\end{tabular}




\section{Appendix 1 (Continued)}

\begin{tabular}{|c|c|c|c|c|c|c|c|}
\hline \multirow[b]{3}{*}{ Variable } & \multirow[b]{3}{*}{ Transformation } & \multicolumn{6}{|c|}{ Economic Activity Indicator } \\
\hline & & \multicolumn{2}{|c|}{ Version 1} & \multicolumn{2}{|c|}{ Version 2} & \multicolumn{2}{|c|}{ Version 3} \\
\hline & & Percent & $\begin{array}{c}\text { Full } \\
\text { Sample }\end{array}$ & Percent & $\begin{array}{c}\text { Full } \\
\text { Sample }\end{array}$ & Percent & $\begin{array}{c}\text { Full } \\
\text { Sample }\end{array}$ \\
\hline $\begin{array}{l}\text { Industrial production: } \\
\text { Electricity, gas, and steam } \\
\text { supply }\end{array}$ & SA by source, log diff & 33 & $\mathrm{x}$ & 7 & $\mathrm{x}$ & 34 & $\mathrm{x}$ \\
\hline $\begin{array}{l}\text { Industrial production: } \\
\text { Info/tech activity in } \\
\text { manufacturing }\end{array}$ & SA by source, log diff & 10 & & 32 & $\mathrm{x}$ & 55 & $\mathrm{x}$ \\
\hline $\begin{array}{l}\text { Index of equipment } \\
\text { investment: Commodities }\end{array}$ & SA by source, log diff & 100 & $\mathrm{x}$ & 39 & $\mathrm{x}$ & 57 & $\mathrm{x}$ \\
\hline $\begin{array}{l}\text { Index of equipment } \\
\text { investment: Other } \\
\text { machinery }\end{array}$ & SA by source, log diff & 100 & $\mathrm{x}$ & 86 & $\mathrm{x}$ & 71 & $\mathrm{x}$ \\
\hline $\begin{array}{l}\text { Index of equipment } \\
\text { investment: Transportation }\end{array}$ & SA by source, log diff & 23 & & 12 & & 63 & $\mathrm{x}$ \\
\hline Production capacity index & SA by Haver, log diff & 25 & & 2 & & 36 & $\mathrm{x}$ \\
\hline $\begin{array}{l}\text { Capacity utilization index: } \\
\text { Manufacturing }\end{array}$ & SA by source, log diff & 96 & $\mathrm{x}$ & 100 & $\mathrm{x}$ & 98 & $\mathrm{x}$ \\
\hline $\begin{array}{l}\text { Manufacturing operation } \\
\text { ratio }\end{array}$ & SA by Haver, log diff & 96 & $\mathrm{x}$ & 100 & $\mathrm{x}$ & 100 & $\mathrm{x}$ \\
\hline Electricity consumption & SA by source, log diff & 4 & & 2 & & 44 & $\mathrm{x}$ \\
\hline $\begin{array}{l}\text { Electricity consumption: } \\
\text { Manufacturing }\end{array}$ & SA by source, log diff & 100 & $\mathrm{x}$ & 93 & $\mathrm{x}$ & 98 & $\mathrm{x}$ \\
\hline $\begin{array}{l}\text { Electricity consumption: } \\
\text { Agriculture, forestry, } \\
\text { fishing, and hunting }\end{array}$ & SA by Haver, log diff & 9 & $\mathrm{x}$ & 1 & & 20 & \\
\hline $\begin{array}{l}\text { Electricity consumption: } \\
\text { Mining and quarrying }\end{array}$ & SA by Haver, log diff & 15 & & 0 & & 18 & \\
\hline $\begin{array}{l}\text { Electricity consumption: } \\
\text { Household }\end{array}$ & SA by Haver, log diff & 82 & $\mathrm{x}$ & 61 & $\mathrm{x}$ & 53 & $\mathrm{x}$ \\
\hline $\begin{array}{l}\text { Electricity consumption: } \\
\text { Public }\end{array}$ & SA by Haver, log diff & 60 & $\mathrm{x}$ & 7 & $\mathrm{x}$ & 68 & $\mathrm{x}$ \\
\hline
\end{tabular}




\section{AppendiX 1 (Continued)}

\begin{tabular}{|c|c|c|c|c|c|c|c|}
\hline \multirow[b]{3}{*}{ Variable } & \multirow[b]{3}{*}{ Transformation } & \multicolumn{6}{|c|}{ Economic Activity Indicator } \\
\hline & & \multicolumn{2}{|c|}{ Version 1} & \multicolumn{2}{|c|}{ Version 2} & \multicolumn{2}{|c|}{ Version 3} \\
\hline & & Percent & $\begin{array}{c}\text { Full } \\
\text { Sample }\end{array}$ & Percent & $\begin{array}{c}\text { Full } \\
\text { Sample }\end{array}$ & Percent & $\begin{array}{c}\text { Full } \\
\text { Sample }\end{array}$ \\
\hline $\begin{array}{l}\text { Electricity consumption: } \\
\text { Service industry }\end{array}$ & SA by Haver, log diff & 63 & $\mathrm{x}$ & 48 & & 31 & \\
\hline Oil and gas production & SA by Haver, log diff & 51 & & 1 & & 49 & $\mathrm{x}$ \\
\hline Petroleum imports & SA by Haver, log diff & 100 & $\mathrm{x}$ & 100 & $\mathrm{x}$ & 86 & $\mathrm{x}$ \\
\hline Domestic consumption & SA by Haver, log diff & 78 & $\mathrm{x}$ & 48 & $\mathrm{x}$ & 70 & $\mathrm{x}$ \\
\hline $\begin{array}{l}\text { Exports of petroleum } \\
\text { products }\end{array}$ & SA by Haver, log diff & 4 & & 1 & & 25 & $\mathrm{x}$ \\
\hline Unemployment & SA by source, log diff & 98 & $\mathrm{x}$ & 26 & & 66 & $\mathrm{x}$ \\
\hline Not in labor force & SA by source, log diff & 46 & $\mathrm{x}$ & 5 & & 33 & \\
\hline Employment & SA by Haver, log diff & 10 & & 1 & & 53 & \\
\hline Output per employed person & SA by source, log diff & 100 & $\mathrm{x}$ & 100 & $\mathrm{x}$ & 95 & $\mathrm{x}$ \\
\hline Shipments & SA by source, log diff & 100 & $\mathrm{x}$ & 100 & $\mathrm{x}$ & 100 & $\mathrm{x}$ \\
\hline $\begin{array}{l}\text { Shipments: Mining and } \\
\text { manufacturing }\end{array}$ & SA by source, log diff & 100 & $\mathrm{x}$ & 100 & $\mathrm{x}$ & 100 & $\mathrm{x}$ \\
\hline Shipments: Domestic market & SA by source, log diff & 86 & & 100 & $\mathrm{x}$ & 100 & $\mathrm{x}$ \\
\hline Machinery orders received & SA by source, log diff & 100 & $\mathrm{x}$ & 87 & $\mathrm{x}$ & 92 & $\mathrm{x}$ \\
\hline $\begin{array}{l}\text { Machinery orders received: } \\
\text { Domestic demand }\end{array}$ & SA by Haver, log diff & 19 & & 0 & & 25 & \\
\hline $\begin{array}{l}\text { Machinery orders received } \\
\text { (ex vessels): Domestic }\end{array}$ & SA by source, log diff & 28 & & 0 & & 34 & $\mathrm{x}$ \\
\hline $\begin{array}{l}\text { Machinery orders received } \\
\text { (ex vessels): Government }\end{array}$ & SA by source, log diff & 2 & & 0 & & 2 & \\
\hline $\begin{array}{l}\text { Machinery orders received } \\
\text { (ex vessels): Private }\end{array}$ & SA by source, log diff & 29 & & 8 & $\mathrm{x}$ & 52 & $\mathrm{x}$ \\
\hline
\end{tabular}




\section{AppendiX 1 (Continued)}

\begin{tabular}{|c|c|c|c|c|c|c|c|}
\hline \multirow[b]{3}{*}{ Variable } & \multirow[b]{3}{*}{ Transformation } & \multicolumn{6}{|c|}{ Economic Activity Indicator } \\
\hline & & \multicolumn{2}{|c|}{ Version 1} & \multicolumn{2}{|c|}{ Version 2} & \multicolumn{2}{|c|}{ Version 3} \\
\hline & & Percent & $\begin{array}{c}\text { Full } \\
\text { Sample }\end{array}$ & Percent & $\begin{array}{c}\text { Full } \\
\text { Sample }\end{array}$ & Percent & $\begin{array}{c}\text { Full } \\
\text { Sample }\end{array}$ \\
\hline $\begin{array}{l}\text { Machinery orders received } \\
\text { (ex vessels): Private, } \\
\text { manufacturing }\end{array}$ & SA by source, $\log$ diff & 16 & & 2 & & 39 & $\mathrm{x}$ \\
\hline $\begin{array}{l}\text { Machinery orders received } \\
\text { (ex vessels): Private, } \\
\text { nonmanufacturing }\end{array}$ & SA by source, log diff & 1 & & 1 & & 36 & \\
\hline Tourist arrivals & SA by Haver, log diff & 34 & $\mathrm{x}$ & 4 & $\mathrm{x}$ & 30 & \\
\hline Tourist arrivals by air & SA by Haver, log diff & 39 & $\mathrm{x}$ & 8 & $\mathrm{x}$ & 42 & $\mathrm{x}$ \\
\hline
\end{tabular}

Notes: In the "Transformation" column, "SA" stands for "seasonally adjusted;" "Haver" refers to "Haver Analytics;" and "log diff" refers to the following transformation: $X_{t}=\ln \left(Y_{t}\right)-\ln \left(Y_{t-12}\right)$, with $X_{t}$ being the transformed variable and $Y_{t}$ being the raw variable. "Percent" denotes the percentage of out-of-sample and full-sample model estimations in which the variable was not dropped. Variables that were not dropped in the full-sample estimation are marked by an $\mathrm{x}$ in the "full-sample" column. 


\section{Appendix 2: Structural Shocks and the Sparse PLS FACTORS}

To make more explicit the relationship between the $r$ PLS factors and the underlying structural shocks, we augment the VAR model (8) with

$$
\begin{aligned}
& \underbrace{\varepsilon_{t}}_{r \times 1}=\underbrace{\Re}_{r \times q} \underbrace{\mathbf{v}_{t}}_{q \times 1} ; \quad r \geq q ; \quad \mathbf{v}_{t} \sim \operatorname{iid}\left(\mathbf{0}, I_{q}\right), \\
& \underbrace{\Re}_{r \times q}=\underbrace{\hat{K}}_{r \times q} \underbrace{\operatorname{diag}\left(\sqrt{\hat{\mu}^{\varepsilon}} \ldots \sqrt{\hat{\mu}^{\varepsilon}}\right)}_{q \times q},
\end{aligned}
$$

where $\varepsilon_{t}$ are the errors from VAR model (8), diag $\left({\sqrt{\hat{\mu}^{\varepsilon}}}_{1} \cdots \sqrt{\hat{\mu}^{\varepsilon}}\right)$ is a matrix with the nonzero elements $\sqrt{\hat{\mu}^{\varepsilon}} 1, \ldots, \sqrt{\hat{\mu}^{\varepsilon}}$ on its main diagonal and zeros everywhere else, $\hat{\mu}_{1}^{\varepsilon}, \ldots, \hat{\mu}_{q}^{\varepsilon}$ are the first $q$ eigenvalues (in descending order) of $\hat{\Omega}^{\varepsilon}$ in (8) and the columns of $\hat{K}$ are the corresponding eigenvectors. All or a subset of the shocks in $\mathrm{v}_{t}$ in $(2 \mathrm{~A})$ can be found by a correspondingly appropriate rotation of the $\Re$ matrix.

Based on $\Omega^{\varepsilon}$ in the VAR model of $r$ PLS factors (8), or the corresponding correlation matrix $\Omega_{\mathrm{C}}^{\varepsilon}$, we follow Bai and $\mathrm{Ng}(2007)$ and consider the following transformations of the eigenvalues of $\Omega^{\varepsilon}$ or $\Omega_{C}^{\varepsilon}$ :

$$
\begin{gathered}
D_{1, k}=\left(\frac{\hat{\mu}_{k+1}^{\varepsilon}}{\sum_{j=1}^{r} \hat{\mu}_{j}^{\varepsilon}}\right)^{1 / 2}, \\
D_{2, k}=\left(\frac{\sum_{j=k+1}^{r} \hat{\mu}_{j}^{\varepsilon}}{\sum_{j=1}^{r} \hat{\mu}_{j}^{\varepsilon}}\right)^{1 / 2},
\end{gathered}
$$

where, as in (2A), $\hat{\mu}_{j}^{\varepsilon}$ is the $j^{\text {th }}$ eigenvalue (in descending order) from either $\Omega_{\varepsilon}$ or $\Omega_{\varepsilon}^{\mathrm{C}}$. Then, by comparing for each $k^{\text {th }}$ eigenvalue $D_{1, k}$ and $D_{2, k}$ to $\frac{1}{\min \left(N^{0.4}, T^{0.4}\right)}$ when the eigenvalues relate to $\Omega^{\varepsilon}$ or comparing $D_{1, k}$ and $D_{2, k}$ to, respectively, $\frac{1.25}{\min \left(N^{0.4}, T^{0.4}\right)}$ and $\frac{2.25}{\min \left(N^{0.4}, T^{0.4}\right)}$ when the eigenvalues relate to $\Omega_{\mathrm{C}}^{\varepsilon}$, one can select to the optimal number of shocks $q$ driving the $r$ PLS factors for those $D_{1, k}$ and $D_{2, k}$ that fall below these threshold values.

Applying this approach to sparse factor model version V3 indicates that this model's eight PLS factors seem to be driven by three or five shocks when applying $D_{1, k}$ to the disturbance covariance matrix or disturbance correlation in (8), respectively, whereas the $D_{2, k}$ in either case suggests two shocks. Bai and $\mathrm{Ng}$ (2007) show in simulations that their tests based on the $D_{1, k}$ measure exhibit better finite sample properties than the ones based on the $D_{2, k}$ when either $N$ (the number of variables underlying the factors) or $T$ (the number of time series) is small. In our case, we combine variable selection with factor extraction, resulting in a relatively small $\mathrm{N}$, and thus the Bai and $\mathrm{Ng}$ (2007) results suggest that it is more likely that fluctuations in the V3 sparse factor economic activity indicator are driven by at least three shocks. 


\section{Notes}

Acknowledgments: The authors thank New York Fed President John C. Williams and an anonymous referee for helpful comments.

${ }^{1}$ It is worth pointing out that there are no regular publications of revisions to GDP growth.

${ }^{2}$ For further discussion of the low volatility of Chinese GDP growth, refer to our companion paper, "How Stable is China's Growth? Shedding Light on Sparse Data" (Clark, Dawson, and Pinkovskiy 2019).

${ }^{3}$ China's prime minister since 2013, Li Keqiang is known for stating that these three series provide a reliable gauge of the state of the Chinese economy.

${ }^{4}$ The bi-weight kernel-based approach will produce a two-sided filter to approximate underlying trends, which then raises the issue of how to compute such a two-sided filter close to the endpoints of the sample. Following Stock and Watson (2012), we deal with these endpoints by truncating the kernel and rescaling the truncated weights so that they add up to 1 .

${ }^{5}$ For robustness, we created a separate index that includes mining, with very similar results.

${ }^{6}$ Like the data on firms' value-added, retail sales data are collected locally and aggregated by the NBS. However, Chen et al. (2019) do show that data collection and aggregation issues are much less of an issue for consumption data. Our main reason to build up our retail sales growth proxy from sectoral data is to be able to strip out the impact of autos and petrol sales.

7 The main reason to apply the X-13 seasonal adjustment, even if we take year-over-year log differences, is to deal in a quasi-automated manner with a number of floating blocs of public holidays that can span across more than one month (most notably the Lunar New Year), which heavily impact Chinese data releases. Any remaining irregularities in the data are then filtered out by our outlier procedure, which is along the lines of the procedure used in Stock and Watson (2012), in which any observation of a series that is above or below this series' historical median value, plus or minus 5 times the interquartile range, is replaced by the historical median value, plus or minus 5 times the interquartile range.

${ }^{8}$ Note that Bai and $\mathrm{Ng}$ (2007) and Stock and Watson (2012) work with factors estimated by means of principal components. Their framework, however, is easily generalizable to our setting, as Kelly and Pruitt (2015) have shown that with an unobserved common factor model PLS regression can be interpreted as selecting those principal component approximations of the unobserved factors that are most relevant for a dependent variable in a regression of this variable on all factors.

${ }^{9}$ Using a version of this global activity instrument where the composing parts are first stripped of contributions of Chinese counterparts (PMI, trade variables) did not materially impact the results as discussed later on in this subsection. 


\section{REFERENCES}

Bai, J., and S. Ng. 2007. "Determining the Number of Primitive Shocks in Factor Models." Journal of Business And EConomic Statistics 25, no. 1 (January): 52-60.

Chen, W., X. Chen, C. Hsieh, and Z. Song. 2019. "A Forensic Examination of China's National Accounts." Brookings Papers on Economic Activity, Spring.

Chun, H., and S. Keles. 2010. "Sparse Partial Least Squares Regression for Simultaneous Dimension Reduction and Variable Selection." Journal of the Royal Statistical Society: Series B (Statistical Methodology) 72, no. 1 (January): 3-25.

Clark, H., J. Dawson, and M. Pinkovskiy. 2020. "How Stable Is China’s Growth? Shedding Light on Sparse Data," Economic Policy Review 26, no. 4 (October): 1-38.

Clark, H., M. Pinkovskiy, and X. Sala-i-Martin. 2020. “China's GDP Growth May Be Understated," ChINA Economic Review 62 (August).

Fernald, J., E. Hsu, and M. Spiegel. 2019. "Is China Fudging Its Figures? Evidence from Trading Partner Data." Federal Reserve Bank of San Francisco Working Paper 2019-19 (August).

Girardin, E., S. Lunven, and G. Ma. 2017. "China’s Evolving Monetary Policy Rule: From InflationAccommodating to Anti-Inflation Policy." Bank for International Settlements BIS WorkING PAPERS, no. 641, May.

Groen, J. J. J., and G. Kapetanios. 2016. "Revisiting Useful Approaches to Data-Rich Macroeconomic Forecasting." Computational Statistics and Data Analysis 100, issue C (August): 221-39.

Kelly, B., and S. Pruitt. 2015. "The Three-Pass Regression Filter: A New Approach to Forecasting Using Many Predictors." Journal of EConometrics 186, no. 2 (June): 294-316.

Krämer, N., and M. Sugiyama. 2011. “The Degrees of Freedom of Partial Least Squares Regression.” Journal of the American Statistical Association 106, no. 494 (June): 697-705.

Mertens, K., and M. O. Ravn. 2013. “The Dynamic Effects of Personal and Corporate Income Tax Changes in the United States.” American Economic Review 103, no. 4 (June): 1212-47.

Stock, J. H., and M. W. Watson. 2012. "Disentangling the Channels of the 2007-2009 Recession," Brookings Papers on ECONOMic ACtivity, Spring, 81-135. 


\section{ECONOMIC POLICYREVIEW}

The Economic Policy Review is published by the Research and Statistics Group of the Federal Reserve Bank of New York. The views expressed are those of the individual authors and do not necessarily reflect the position of the Federal Reserve Bank of New York or the Federal Reserve System.

Series Editor: Julian di Giovanni. Editorial Staff: Robert Powell, Trevor Delaney, Maureen Egan, Anna Snider, and Peter Stevens. Design Staff: Theresa Izzillo, Laura Gharrity, and Jessica Iannuzzi.

Economic Policy Review articles may be reproduced for educational or training purposes, provided they are reprinted in full; include credit to the author(s), the publication, and the Bank; and include the publication's disclaimer.

(C2020 The Federal Reserve Bank of New York

www.newyorkfed.org/research

Follow us on Twitter: @NYFedResearch 